\begin{tabular}{|c|l|}
\hline Title & $\begin{array}{l}\text { Removal of Pollutants from W ater by Using Single W alled Carbon Nanotubes (SWCNT s) and Multi-walled Carbon } \\
\text { Nanotubes (MWCNTs) }\end{array}$ \\
\hline Author(s) & $\begin{array}{l}\text { Rahman, Md Mostafizur; Sime, Sanjida A kter; Hossain, M. A nwar; Shammi, Mashura; Uddin, Md. Khabir; Sikder, Md. } \\
\text { Tajuddin; Kurasaki, Masaaki }\end{array}$ \\
\hline Citation & $\begin{array}{l}\text { A rabian journal for science and engineering, 42(1), 261-269 } \\
\text { https://doi.org/10.1007/313369-016-2303-3 }\end{array}$ \\
\hline Issue Date & 2017-01 \\
\hline Doc URL & http://hdl.handle.net/2115/68042 \\
\hline Rights & The final publication is available at link.springer.com \\
\hline Type & article (author version) \\
\hline File Information & Manuscript Final Revised.pdf \\
\hline
\end{tabular}

Instructions for use 


\title{
Removal of Pollutants from Water by Using Single-walled Carbon Nanotubes (SWCNTs) and Multi-walled Carbon Nanotubes (MWCNTs)
}

Md. Mostafizur Rahman ${ }^{1,2 *}$, Sanjida Akter Sime ${ }^{1}$, M. Anwar Hossain ${ }^{1,3}$, Mashura Shammi $^{1}$, Md. Khabir Uddin ${ }^{1}$, Md. Tajuddin Sikder ${ }^{1,2,4}$, Masaaki Kurasaki ${ }^{2}$

${ }^{1}$ Department of Environmental Sciences, Jahangirnagar University, Dhaka-1342, Bangladesh.

${ }^{2}$ Faculty of Environmental Earth Science, Hokkaido University, Sapporo 060-0810, Japan ${ }^{3}$ Communication Division, Civil Aviation Authority of Bangladesh, Dhaka-1229, Bangladesh

${ }^{4}$ Department of Public Health \& Informatics, Jahangirnagar University, Dhaka-1342, Bangladesh.

*Corresponding author E-mail: rahmanmm@juniv.edu,

Tel: (011) 706-2204 ext.2252, Fax: (011) 706-4867

\begin{abstract}
Water crisis is one of the supreme challenges worldwide as clean water is the ultimate need for human civilization and all other life on earth. In the present study, continuous adsorption experiments were carried out in an adsorption column to survey the efficiency of the carbon nanotubes (CNTs) for removal of pollutants from water/wastewater in terms of physicochemical parameters, such as electrical conductivity (EC), total dissolved solids (TDS), $\mathrm{pH}$, chemical oxygen demand (COD) and total organic carbon (TOC) by using both single-walled carbon nanotubes (SWCNTs) and multi-walled carbon nanotubes (MWCNTs). Sample solutions were allowed to flow in down flow mode through the fixed-bed of CNTs. The CNTs column showed a reduction efficiency of electrical
\end{abstract}


conductivity $80 \%$ from effluent treatment plant (ETP) treated water sample, $69.23 \%$ from raw effluent sample, and $53.33 \%$ from the synthetic salt water sample. Similarly, the efficiency of total dissolved solids reduction were $78.61 \%$ from raw effluent sample, $66.86 \%$ from ETP treated water sample and $62.02 \%$ from the synthetic salt water sample. COD also reduced $84.71 \%$ from raw effluent sample and $39.58 \%$ from the ETP treated water sample. In case of TOC, the column showed a reduction efficiency of $85.88 \%$ from the ETP treated water sample and $70.79 \%$ from the raw effluent sample. These findings suggested that CNTs present a great potential in removal of pollutants in terms of physicochemical parameters from water/wastewater.

Keywords: Carbon Nanotubes, Physicochemical Parameters, Adsorption-filtration wastewater, Water pollution

\section{Abbreviations}

CNTs Carbon Nanotubes

EC Electrical Conductivity

ETP Effluent Treatment Plant

TDS Total Dissolved Solids

COD Chemical Oxygen Demand

TOC Total Organic Carbon

SWCNTs Single-walled Carbon Nanotubes

(MWCNTs) Multi-walled Carbon Nanotubes 


\section{Introduction}

Water demand is growing rapidly as a result of increasing population and rapid urbanization and industrialization degrading the water quality [1]. The lack of clean and affordable water brings about 2 million deaths a year, either directly through dehydration or indirectly through grievous illnesses [2]. Worldwide, some 780 million people still lack access to improved drinking water sources [3]. Water resources are limited in populated areas, such as Bangladesh and other developing countries. The surface water is polluted due to several domestic, municipal, agricultural and various industrial activities, which makes the water unfit for human consumption and other usage [4]. Various types of pollutions of water boost up the water scarcity problem. The deficiency of water resources calls for efficient technologies for wastewater recovery and seawater desalination and recently pollution exacerbates the water shortage problems. Various conventional \& advanced water treatment technologies such as coagulation \& flocculation, membrane filtration, microfiltration, ultrafiltration, adsorption, reverse osmosis, ozonation etc. has been adopted for the treatment of wastewater in our country. But, existing water and wastewater treatment technologies and infrastructure are reaching their limit for providing adequate water quality to meet human and environmental needs.

\subsection{Carbon nanotubes}

Nanotechnology provides a significant technology platform in water purification sector as nanoscience works at the molecular level, atom by atom, to create larger structures with fundamentally new molecular organization, novel properties and functions [5-6]. As a relatively modern subject in science, CNTs first observed by physicist Sumio Iijima in 1991 [2]. CNTs, a new form of pure carbon with diameter in nanometers, length in microns are perfectly straight tubules [7]. The walls of these tubes are constructed of a hexagonal lattice 
of carbon atoms and capped by fullerene-like structures. The unique structure of CNTs can be divided mainly into multi-walled carbon nanotubes (MWCNTs) and single-walled carbon nanotubes (SWCNTs) [8]. CNTs have an exceptional sorption capability and high sorption efficiency with their high surface active site to volume ratio and controlled pore size distribution, compared to conventional granular and powder activated carbon [8]. CNTs show adsorption capability and high adsorption efficiency for removal of organic pollutants like 1, 2-dichlorobenzene, trihalomethanes, n-nonane, and carbon tetrachloride $\left(\mathrm{CCl}_{4}\right)$ [913], heavy metals (e.g., $\mathrm{Cu}^{2+}, \mathrm{Pb}^{2+}, \mathrm{Cd}^{2+}$, and $\mathrm{Zn}^{2+}$ ) such as oxidized CNTs with $\mathrm{H}_{2} \mathrm{O}_{2}$, $\mathrm{KMnO}_{4}$, and $\mathrm{HNO}_{3}$ [14-15] from water, Fluoride adsorbed from water by amorphous $\mathrm{Al}_{2} \mathrm{O} 3$ supported on carbon nanotubes $\left(\mathrm{Al}_{2} \mathrm{O}_{3} / \mathrm{CNTs}\right)$ [16]. This study has been carried out to investigate the efficiency of CNTs as an adsorbing material from raw effluents; ETP treated effluent and synthetic salt water wastewater.

\section{Materials and methods}

\subsection{Preparation of adsorption column}

The column has been packed with both SWCNTs and MWCNTs (Fig. 1). The packing materials consists a height of $15 \mathrm{~cm}$ and diameter $4 \mathrm{~cm}$ of the Pyrex glass tube (column) with a length of $46 \mathrm{~cm}$ (Fig. 2). The packing materials were weighted in Digital Balance, JD210-4. The weight of SWCNTs and MWCNTs were $43.36 \mathrm{~g}$ and $10.42 \mathrm{~g}$, respectively. Packing density was $0.02326 \mathrm{gm} / \mathrm{cm}^{3}$. Three different types of sample water has been used for this experiment such as- raw textile effluent (I), textile effluent treated by ETP (O) \& synthetic salt water (S) prepared in laboratory.

(Fig. 1 is to be inserted here) 


\subsection{Characterization of the CNTs with SEM and TEM}

Images of the polymer were recorded using a Hitachi S-4000 scanning electron microscope (SEM; Ibaraki, Japan) on aluminum stubs adhered to graphite support units using carbon tape [17]. Transmission electron microscopy (TEM) images were obtained by dispersed the CNTs homogeneously in 2-propanol under ultrasonication for $30 \mathrm{~min}$. A few drops of the suspension were deposited on the TEM grid covered with a Formvar membrane, dried, and evacuated before analysis. Ultra-thin sections were stained with $2 \%$ uranyl acetate and lead citrate. The preparations were observed using a Hitachi H-800 TEM. The acceleration voltage was $75 \mathrm{kV}$.

\subsection{Experimental steps}

Continuous fixed-bed experiments were performed to remove impurities from aqueous solutions using CNTs as adsorbent. First, $500 \mathrm{ml}$ of distilled water was passed through the packed bed to make the packing more compact packing. Sample solutions were allowed to flow in down flow mode through the fixed-bed of CNTs controlled by a valve with a different flow rate like 2, 4, 6, 8, 10, 12, 14, 16, 18, $20 \mathrm{ml} / \mathrm{min}$.

Total $1000 \mathrm{ml}$ water has been passed through the column of each sample, and each $100 \mathrm{ml}$ of treated water collected separately after column treatment. Each of $100 \mathrm{ml}$ treated water of $1000 \mathrm{ml}$ i.e., $1^{\text {st }} 100 \mathrm{ml}$ to $10^{\text {th }} 100 \mathrm{ml}$ step leveled as A, B, C, D, E, F, G, H, I and J, respectively. The treated water of each sample collected in ten separate beakers, and each beaker contained $100 \mathrm{ml}$ collected water separately with 3 replications. The treated water was collected properly and various physicochemical measurements, like as, $\mathrm{pH}$, EC, COD (Chemical Oxygen Demand), TDS (Total Dissolved Solids), EC (Electrical Conductivity), TOC (total Organic Carbon) were done by appropriate equipment and method to measure the parameters and compare the results with previous physicochemical measurements. 
(Fig. 2 is to be inserted here)

The column efficiency for different parameter (such as pH, COD, TDS, EC, TOC) has presented in percentage. In the raw textile effluent (I) and ETP treated industrial effluent (O), physicochemical parameters, EC, TDS, pH, COD and TOC(NPOC) were observed $3900 \mu \mathrm{S} / \mathrm{cm}, 2620 \mathrm{mg} / \mathrm{l}, 10.9,788.8 \mathrm{mg} / \mathrm{l}, 1010 \mathrm{mg} / \mathrm{l}$, respectively and $500 \mu \mathrm{S} / \mathrm{cm}, 528$ mg/l, 6.7, 132.4 mg/l, 45.81mg/l, respectively (Table 1).

(Table 1 is to be inserted here)

Efficiency $(\%)=(A-B) / A \times 100 \%$; Where, $A=$ Initial value and $B=$ Final value .

All of the data were subjected to statistical analysis using MSTAT version 1.2.

\section{Results and discussion}

\subsection{Characterization of the CNTs with SEM and TEM}

The morphology of CNTs was understood using SEM images. Fig. 3(a-b) showed typical SEM images revealing the morphology of the of the CNTs. The ribbon shaped CNTs were observed which exhibited chemisorption properties to bind target materials in solution. Fig. 3(c-d) shows a TEM image of the CNTs, which exhibited a typical smooth, porous and crisscrossed structure with the corrugation and scrolling that are fundamental to similar types of materials. The morphological characterization of CNTs revealed that these compounds are capable to bind and remove the targeted materials from solution.

Fig. 3 (a) SEM images of carbon nanotubes bundles; (b) SEM micrograph of SWCNTs; (c) TEM images of SWCNTs and (d) TEM images of MWCNTs. 


\subsection{Analysis of the physicochemical parameters}

Various types of pollution loads are presents in textile wastewater in terms of high $\mathrm{pH}$, temperature, COD, TDS, EC and TOC of the sample water have been determined before and after the treatment procedure to observe the significant changes.

\subsubsection{Electric conductivity reduction}

Electric conductivity of the raw effluent, ETP treated effluent and synthetic salt water reduced after treatment by CNTs. It is observed that, CNTs has excellent efficiency to remove pollutants from wastewater in the field of water treatment technology. The results show that the column made with CNTs can efficiently reduce the extent of pollutants in terms of physicochemical parameters from the collected sample water.

After treatment by CNTs electrical conductivity (EC) of the raw effluents were observed as $1201 \mu \mathrm{S} / \mathrm{cm}$ for the $1^{\text {st }} 100 \mathrm{ml}$ treated effluent (I) and the maximum (3111 $\left.\mu \mathrm{S} / \mathrm{cm}\right)$ was observed in $10^{\text {th }} 100 \mathrm{ml}$ treated effluent(I) which was less than the initial value $(3900$ $\mu \mathrm{S} / \mathrm{cm})$. For ETP treated effluent, it was observed as a $100 \mu \mathrm{S} / \mathrm{cm}, 400 \mu \mathrm{S} / \mathrm{cm}, 492 \mu \mathrm{S} / \mathrm{cm}$, for the $1^{\text {st }} 100 \mathrm{ml}, 2^{\text {nd }} 200 \mathrm{ml}$ and $3^{\text {rd }} 100 \mathrm{ml}$, respectively. In synthetic salt water, EC of the treated water were observed as $1400 \mu \mathrm{S} / \mathrm{cm}, 2990 \mu \mathrm{S} / \mathrm{cm}$ and $3009 \mu \mathrm{S} / \mathrm{cm}$ for $1^{\text {st }} 100 \mathrm{ml}$, $2^{\text {nd }} 100 \mathrm{ml}$ and the $3^{\text {rd }} 100 \mathrm{ml}$, respectively (Table 2).

(Table 2 is to be inserted here)

Carbon nanotubes hold great potential for various applications because of their unique properties, such as high thermal and electrical conductivities, high strength, high stiffness, and special adsorption properties [18]. Carbon nanotubes have cylindrical pores and adsorbent molecules interact with their carbon atoms on the surrounding walls. This interaction between molecules and solid surface depends on the pore size and geometry of 
pores. When a molecule is placed in between two flat surfaces, i.e., in a slit- shaped pore, it interacts with both surfaces, and the potentials on the two surfaces overlap. The extent of the overlap depends on the pore size [19]. However, for cylindrical and spherical pores, the potentials are greater because more surface atoms interact with the adsorbed molecule [18]. In addition, carbon nanotubes are highly graphitic (much more than the activated carbons). Hence, the carbon nanotubes can absorb molecules much stronger than activated carbons, which have slit-shaped or wedge-shaped pores [18].

Maximum EC removals were observed in the treatment of $1^{\text {st }} 100 \mathrm{ml}$ for all three types of wastewater. Maximum EC removal efficiency for raw effluent (I), ETP treated effluent(O), synthetic salt water were observed as $69.21 \%, 80.20 \%$ and $54.69 \%$, respectively. The EC removal for raw effluent (I) were observed as $23.00 \%, 22.90 \%$, $23.157 \%$ and $23.18 \%$ for the treatment of $2^{\text {nd }} 100 \mathrm{ml}, 3^{\text {rd }} 100 \mathrm{ml}, 4^{\text {th }} 100 \mathrm{ml}$ and $10^{\text {th }} 100 \mathrm{ml}$, respectively (Fig. 4).

(Fig. 4 is to be inserted here)

For ETP treated effluent EC removal was observed as 20.79\%, 2.93\%, $0.79 \%$ and $0.99 \%$ for the treatment of $2^{\text {nd }} 100 \mathrm{ml}, 3^{\text {rd }} 100 \mathrm{ml}, 4^{\text {th }} 100 \mathrm{ml}$ and $10^{\text {th }} 100 \mathrm{ml}$, respectively. For synthetic salt water efficiency of EC removal were observed as $3.24 \%, 2.62 \%, 2.54 \%$ and $0.29 \%$ for the treatment of $2^{\text {nd }} 100 \mathrm{ml}, 3^{\text {rd }} 100 \mathrm{ml}, 4^{\text {th }} 100 \mathrm{ml}$ and $10^{\text {th }} 100 \mathrm{ml}$, respectively.

The experiment of this work shows that, the CNTs column can remove EC 80\% from ETP treated water sample (O), 69.23\% from the raw effluent sample (I) and 53.33\% from the synthetic salt water sample (S). Its high adsorption capacity mainly stems from the large specific surface area and the diverse contaminant-CNT interactions. According to several studies, SWCNT filters are ideal for water desalination because of their small sizes and their 
hydrophobic structures. The salt ion is trapped in the middle of the nanotube structure. Depending on the size of the nanotube, $60 \%$ to $100 \%$ of ions are successfully filtered from the water [20].

\subsubsection{Effects on pH}

After treatment by CNTs water $\mathrm{pH}$ vary significantly. In raw effluents, $\mathrm{pH}$ was observed as 9.50, 9.52 and 9.60 for the $1^{\text {st }} 100 \mathrm{ml}, 2^{\text {nd }} 100 \mathrm{ml}$ and $3^{\text {rd }} 100 \mathrm{ml}$ respectively. Maximum $\mathrm{pH}$ value was observed in $6^{\text {th }} 100 \mathrm{ml}$ (9.89) which was less than the initial $\mathrm{pH}$ value (10.90). For ETP treated effluent, it was observed as 6.92, 7.48, 7.45 for the treatment of $1^{\text {st }} 100 \mathrm{ml}$, $2^{\text {nd }} 100 \mathrm{ml}$ and $3^{\text {rd }} 100 \mathrm{ml}$, respectively. In synthetic salt water, $\mathrm{pH}$ of the treated water was observed as $8.95,8.95$ and 8.63 for the treatment of $1^{\text {st }} 100 \mathrm{ml}, 2^{\text {nd }} 100 \mathrm{ml}$ and the $3^{\text {rd }} 100$ ml treated water, respectively (Table 3).

(Table 3 is to be inserted here)

The $\mathrm{pH}$ variation efficiency of raw effluent(I) for $1^{\text {st }} 100 \mathrm{ml}$ to $10^{\text {th }} 100 \mathrm{ml}$ were observed as 12.84\%, 12.66\%, 11.92\%, 11.19\%, 10.18\%, 9.27\%, 10.92\%, 10.92\%, 11.65\%, and $11.92 \%$, respectively. Maximum $\mathrm{pH}$ variation efficiency was observed $(12.48 \%)$ in the treatment of $2^{\text {nd }} 100 \mathrm{ml}$, for ETP treated effluent $(\mathrm{O})$, and for synthetic salt water, it was observed (26.95\%) in both of $1^{\text {st }} 100 \mathrm{ml}$ and $2^{\text {nd }} 100 \mathrm{ml}$ of the treatment (Fig. 5).

\section{(Fig. 5 is to be inserted here)}

Significant changes of $\mathrm{pH}$ have been observed after the column experiment with CNTs in this study. $\mathrm{pH}$ has reduced up to $12.84 \%$ for sample (I), and all the values of three samples after treatment, is within the recommended value. The $\mathrm{pH}$ is of major importance in determining the corrosivity of water. In general, the lower the $\mathrm{pH}$, the higher the level of 
corrosion. Exposure to extreme $\mathrm{pH}$ values results in various health effects such as irritation to the eyes, skin, and mucous membranes. $\mathrm{pH}$ values greater than 11 causes eye irritation and skin disorders; solutions of $\mathrm{pH}$ 10-12 causes hair fibers to swell and sometimes in sensitive individuals, gastrointestinal irritation may also occur. Below $\mathrm{pH} 4$, redness and irritation of the eyes have been reported \& below $\mathrm{pH} 2.5$, damage to the epithelium is irreversible and extensive [21].

\subsubsection{Effect on TDS}

Total dissolved solid of the three types of effluent significantly varied after treatment by CNTs. In raw effluents, TDS was observed as $55.00 \mathrm{mg} / \mathrm{L}, 11.00 \mathrm{mg} / \mathrm{L}$ and $11.20 \mathrm{mg} / \mathrm{L}$ for the $1^{\text {st }} 100 \mathrm{ml}, 2^{\text {nd }} 100 \mathrm{ml}$ and $3^{\text {rd }} 100 \mathrm{ml}$ respectively. Maximum TDS value was observed in $5^{\text {th }} 100 \mathrm{ml}(15.30 \mathrm{mg} / \mathrm{L})$ which was less than the initial TDS value $(26.00 \mathrm{mg} / \mathrm{L})$. For ETP treated effluent, it was observed as $17.00 \mathrm{mg} / \mathrm{L}, 41.00 \mathrm{mg} / \mathrm{L}$ and $46.00 \mathrm{mg} / \mathrm{L}$ for the treatment of $1^{\text {st }} 100 \mathrm{ml}, 200 \mathrm{ml}$ and $3 \mathrm{dr} 100 \mathrm{ml}$ wastewater, respectively. In synthetic salt water, TDS of the treated wastewater was observed as $61.00 \mathrm{mg} / \mathrm{L}, 16.00 \mathrm{mg} / \mathrm{L}$ and 14.90 $\mathrm{mg} / \mathrm{L}$ for the treatment of $1^{\text {st }} 100 \mathrm{ml}, 2^{\text {nd }} 100 \mathrm{ml}$ and the $3^{\text {rd }} 100 \mathrm{ml}$ treated water, respectively (Table 4$)$.

(Table 4 is to be inserted here)

The TDS removal efficiency of raw effluent (I) were observed as 23.08\%, 57.69\%, 56.92\%, $42.31 \%, 41.15 \%, 57.31 \%, 56.92 \%, 57.69 \%$ and $57.69 \%$ for the treatment of $1^{\text {st }} 100 \mathrm{ml}$ to $10^{\text {th }} 100 \mathrm{ml}$, respectively.

The TDS removal efficiency for ETP treated effluent were observed as 67.31\%, $21.15 \%$ $11.54 \%$ 0.83\%, 11.93\%, 1.51\%, 0.57\%, 10.61\%, 9.09\%, 6.82\%, 6.82 and $6.82 \%$ for the treatment of $1^{\text {st }} 100 \mathrm{ml}, 2^{\text {nd }} 100 \mathrm{ml}$ and $3^{\text {rd }} 100 \mathrm{ml}$, respectively. Treatment of $4^{\text {th }} 100 \mathrm{ml}$ and $5^{\text {th }} 100 \mathrm{ml}$ observed $0 \%$ efficiency. 
For synthetic salt water, the TDS removal efficiency were observed as $31.25 \%, 6.88 \%$ and 6.25\% for the treatment of $2^{\text {nd }} 100 \mathrm{ml}, 3^{\text {rd }} 100 \mathrm{ml}$ and $4^{\text {th }} 100 \mathrm{ml}$, respectively (Fig. 6).

\section{(Fig. 6 is to be inserted here)}

From this study it is found that, the TDS load of the sample water has been reduced significantly after treatment with CNTs. The CNTs column significantly remove TDS 78.61\% from the raw effluent sample (I), 66.86\% from the ETP treated water sample (O) and $62.02 \%$ from the synthetic salt water sample (S). The nano-tubes act as a kind of molecular filter, allowing smaller molecules (such as water) to pass through the tubes, while contaminants are too large to pass through. Due to their electronic configuration smaller ions that would otherwise pass through are also blocked [22].

\subsubsection{Effects on COD}

Chemical Oxygen demand CNTs treated effluent significantly varied. In raw effluents, COD was observed as $120.30 \mathrm{mg} / \mathrm{L}, 198.50 \mathrm{mg} / \mathrm{L}$ and $286.60 \mathrm{mg} / \mathrm{L}$ for the $1^{\text {st }} 100 \mathrm{ml}, 2^{\text {nd }}$ $100 \mathrm{ml}$ and $3^{\text {rd }} 100 \mathrm{ml}$ respectively. Maximum COD value was observed in $5^{\text {th }} 100 \mathrm{ml}$ (473.10 mg/L) which was less than the initial COD value $(788.80 \mathrm{mg} / \mathrm{L})$. For ETP treated effluent, it was observed as $80.00 \mathrm{mg} / \mathrm{L}, 92.70 \mathrm{mg} / \mathrm{L}$ and $102.00 \mathrm{mg} / \mathrm{L}$ for the treatment of $1^{\text {st }} 100 \mathrm{ml}, 2^{\text {nd }} 100 \mathrm{ml}$ and $3^{\text {rd }} 100 \mathrm{ml}$ wastewater, respectively (Table 5).

\section{(Table 5 is to be inserted here)}

The maximum COD removal efficiency for both of raw effluent (I) and ETP treated effluent (O) were observed for the treatment of $1^{\text {st }} 100 \mathrm{ml}$, which were $84.75 \%$ and $39.57 \%$, respectively. Efficiency of COD removal were observed as 74.84\%, 63.67\%, 53.06\%, $40.02 \%, 46.63 \%, 42.93 \%, 49.70 \%, 53.00 \%$ and $55.01 \%$ for the treatment $2^{\text {nd }} 100 \mathrm{ml}$, to $10^{\text {th }}$ 
$100 \mathrm{ml}$, respectively for raw effluent and 29.98\%, 22.96\%, 23.79, 27.64\%, 26.74\%, $24.92 \%, 24.02 \% 29.15 \%$ and $28.10 \%$ for the treatment $2^{\text {nd }} 100 \mathrm{ml}$, to $10^{\text {th }} 100 \mathrm{ml}$, respectively for ETP treated effluents (Fig. 7).

(Fig. 7 is to be inserted here)

The present study have shown that, the CNTs column removed COD $84.75 \%$ from the raw effluent sample (I) and 39.57\% from the ETP treated water sample (O). Because of the hydrophobic nature of their outer surfaces, CNTs have a strong affinity to organic chemicals, especially to nonpolar organic compounds, such as naphthalene, phenanthrene, and pyrene [23]. The morphology of CNTs including nanoscale curvature and chirality of graphene layers is expected to have a great influence on the adsorption of organic pollutants. Although activated carbon possesses comparable measured specific surface area as CNT bundles, it contains a significant number of micropores inaccessible to bulky organic molecules such as many antibiotics and pharmaceuticals. Thus CNTs have much higher adsorption capacity for some bulky organic molecules because of their larger pores in bundles and more accessible sorption sites.

\subsubsection{Effect on TOC (NPOC)}

Effect on TOC (NPOC) significantly varied after treatment of wastewater by CNTs . In raw effluents, TOC was observed as $295.00 \mathrm{mg} / \mathrm{L}, 348.80 \mathrm{mg} / \mathrm{L}$ and $480.90 \mathrm{mg} / \mathrm{L}$ for the treatment of $1^{\text {st }} 100 \mathrm{ml}, 2^{\text {nd }} 100 \mathrm{ml}$ and $3^{\text {rd }} 100 \mathrm{ml}$, respectively. Maximum TOC value was observed in $5^{\text {th }} 100 \mathrm{ml}(656.50 \mathrm{mg} / \mathrm{L})$ which was less than the initial TOC value $(1010.00$ $\mathrm{mg} / \mathrm{L}$ ). For ETP treated effluent, it was observed as $6.47 \mathrm{mg} / \mathrm{L}, 7.20 \mathrm{mg} / \mathrm{L}$ and $7.01 \mathrm{mg} / \mathrm{L}$ for the treatment of $1^{\text {st }} 100 \mathrm{ml}, 2^{\text {nd }} 100 \mathrm{ml}$ and $3^{\text {rd }} 100 \mathrm{ml}$ wastewater, respectively. Maximum TOC was observed as $8.14 \mathrm{mg} / \mathrm{L}$ in the treatment of $4^{\text {th }} 100 \mathrm{ml}$ (Table 6). 


\section{(Table 6 is to be inserted here)}

In the present study it is found that the load of total organic carbon (TOC) has been reduced significantly. Maximum TOC removal efficiency were observed in the treatment of $1^{\text {st }} 100$ $\mathrm{ml}$ as $70.79 \%$ and $85.88 \%$ for both of raw effluent (I) and ETP treated effluent (O), respectively. the TOC removal efficiency for raw effluent were observed as $65.47 \%$, $52.39 \%, 43.50 \%, 35.00 \%, 42.50 \%, 48.48 \%, 47.51 \%, 49.24 \%$ and $51.23 \%$ for $2^{\text {nd }} 100 \mathrm{ml}$ to $10^{\text {th }} 100 \mathrm{ml}$, respectively. For ETP treated effluent $84.28 \%, 84.70 \%, 82.23 \%, 83.85 \%$, $82.71 \%, 82.51 \%, 84.94 \%, 84.15 \%$ and $84.46 \%$ for $2^{\text {nd }} 100 \mathrm{ml}$ to $10^{\text {th }} 100 \mathrm{ml}$, respectively (Fig. 8).

\section{(Fig. 8 is to be inserted here)}

The column experiment in this study has shown significant reduction of TOC from the water samples. The CNTs column can remove TOC 85.88\% from the ETP treated water sample O and $70.79 \%$ from the raw effluent sample (I). CNTs have higher efficiency on adsorption of various organic chemicals [24]. In the aqueous phase, CNTs form loose bundles/aggregates due to the hydrophobicity of their graphitic surface, reducing the effective surface area. On the other hand, CNT aggregates contain interstitial spaces and grooves, which are high adsorption energy sites for organic molecules [24].

TOC detection is an important measurement because of the effects it may have on the environment, human health, and manufacturing processes. TOC is a highly sensitive, non-specific measurement of all organics present in a sample. It, therefore, can be used to regulate the organic chemical discharge to the environment in a manufacturing plant. In addition, low TOC can confirm the absence of potentially harmful organic chemicals in water used to manufacture pharmaceutical products. TOC is also of interest in the field of 
potable water purification due to disinfection of byproducts. Inorganic carbon poses little to no threat.

As revealed in Fig. 6 the TDS removal efficiency of the raw effluent (O) was initially $78.61 \%$ for $1^{\text {st }} 100 \mathrm{ml}$ treated water. But it decreases gradually to $57.06 \%, 57.06 \%$, $39.69 \%$, 39.04\% and then again a few increases to $57.25 \%, 55.72 \%, 55.34 \%, 54.89 \%$, and $54.58 \%$ respectively, but not as the initial value. If the packing materials in columns are being washed with de-ionized water, then the column perform very well as before, with a very high efficiency. But, it's a problem to wash the column materials again and again in a continuous adsorption experiment. So, this is the main limitation of this study.

CNTs, with their unusual properties, large sorption capacity, wide surface area and the presence of a wide spectrum of surface functional groups have generated a great interest in their use as sorbent materials in a wide variety of analytical processes. The presence of the inner cavities, active sites on the surface and inter nanotube space can contribute to the high pollutants removal capability of CNTs. In several comparative studies the results showed that CNTs were more effective than or as effective as other commonly used adsorbents such as C 18 bonded silica, activated carbon or macro porous resins. It was reported that CNTs may be re-used more than 100 times after proper cleaning and reconditioning. Carbon nanotubes have excellent adsorption ability for many kinds of substances such as inorganic and organic compounds. Smaller carbon nanotubes, such as SWNTs could potentially be used as a future desalinator, due to their size and ability to filter out the small ion particles found in seawater [2]. So, CNTs can play very important role in the field of water/wastewater treatment and purification technology.

Carbon nanotubes are relatively expensive and upon large scale application, there are several issues that must be overcome in order to make them feasible practically. The high cost of synthesis is always one of the main issues blocking the application of CNTs on 
a larger scale. However, recent experimental studies have demonstrated the possibility of mass producing high quality CNTs at lower cost [7, 25-26]. The possibility of mass production of CNTs has catalyzed the vision to commercialize and apply CNT technology in large scale applications [8]. As a new and emerging technology, CNTs can be used from pilot scale to larger scale application in water treatment processes, such as in household water purification facilities and in industrial sectors.

\subsubsection{Comparative analysis with other conventional low-cost adsorbents}

This study also revealed that CNTs have high potential to separate large quantity of pollutants compared with other conventional low-cost adsorbents (Table 7). In this study, we investigated that a large number of researches were so far conducted to remove the EC, TDS, COD and TOC where synthesized natural materials ranked high in terms of efficiency. Among all those materials, activated charcoal, wood ash and bagasse were found the most effective ones. In case of $\mathrm{pH}$, CNTs showed the $\mathrm{pH}$ increases significantly high in solution in compare with the synthesized materials that indicated that the pollutants compounds present in water either neutralize or reduce by the effect of CNTs. The concentration of COD, TDS, EC and TOC were reduced drastically from solution in compare with the high efficient activated charcoal, wood ash and bagasse [27]. Wang et al. (2009) and Deepa et al. (2015) also found similar results in case of COD and TDS, respectively [28-29]. So, it can be stated that the CNTs induced nanotechnology will be efficient on an industrial scale.

(Table 7 is to be inserted here)

\section{Conclusion}

In this study feasibility of CNTs column adsorption in removal of pollutants in terms of physicochemical parameters was investigated. The parameters such as electrical 
conductivity (EC), total dissolved solids (TDS), $\mathrm{pH}$, chemical oxygen demand (COD) and total organic carbon (TOC) of all samples were studied before and after the treatment with CNTs. The results showed efficient reduction in EC, TDS, $\mathrm{pH}, \mathrm{COD}$ and TOC from their initial value. The efficiency of CNTs, both SWCNTs and MWCNTs as an adsorbing material in removal of pollutants in terms of physicochemical parameters were significant.

\section{List of Figures caption}

Fig. 1 Multi-walled carbon nanotubes (MWCNTs) and Single-walled carbon nanotubes (SWCNTs)

Fig. 2 Experimental column with passing sample solutions

Fig. 3 (a) SEM images of carbon nanotubes bundles; (b) SEM micrograph of SWCNTs; (c) TEM images of SWCNTs and (d) TEM images of MWCNTs.

Fig. 4 Efficiency of CNTs for Electric conductivity removal of raw industrial effluent, ETP treated industrial effluent and synthetic salt water

Fig. 5 Efficiency of CNTs in pH variation of raw industrial effluent, ETP treated industrial effluent and synthetic salt water

Fig. 6 Efficiency of CNTs for TDS removal of raw industrial effluent, ETP treated industrial effluent and synthetic salt water

Fig. 7 Efficiency of CNTs for COD removal of raw industrial effluent and ETP treated effluent

Fig. 8 Efficiency of CNTs for TOC (NPOC) removal of raw effluent and ETP treated effluent 


\section{List of Tables}

Table 1 The physicochemical parameters wastewater before treatment

Table 2 Determination of changes in EC after treatment by CNTs

Table 3 Determination of changes in $\mathrm{pH}$ after treatment by CNTs

Table 4 Determination of changes in TDS after treatment by CNTs

Table 5 Determination of changes in COD after treatment by CNTs

Table 6 Determination of changes in TOC (NPOC) after treatment by CNTs

Table 7 Comparative analysis of removal efficiency of CNTs with some low-cost efficient adsorbents.

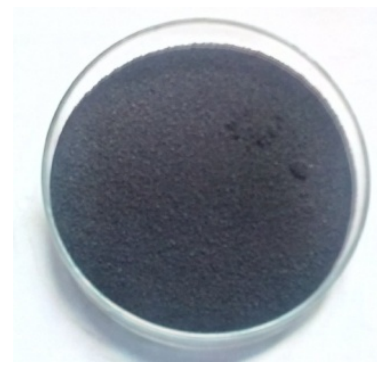

(a) MWCNTs

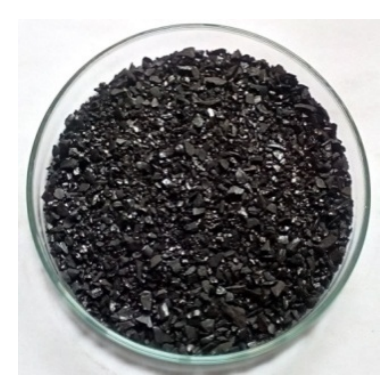

(b) SWCNTs

Fig. 1 (a) Multi-walled carbon nanotubes (MWCNTs) and (b) Single-walled carbon nanotubes (SWCNTs) 


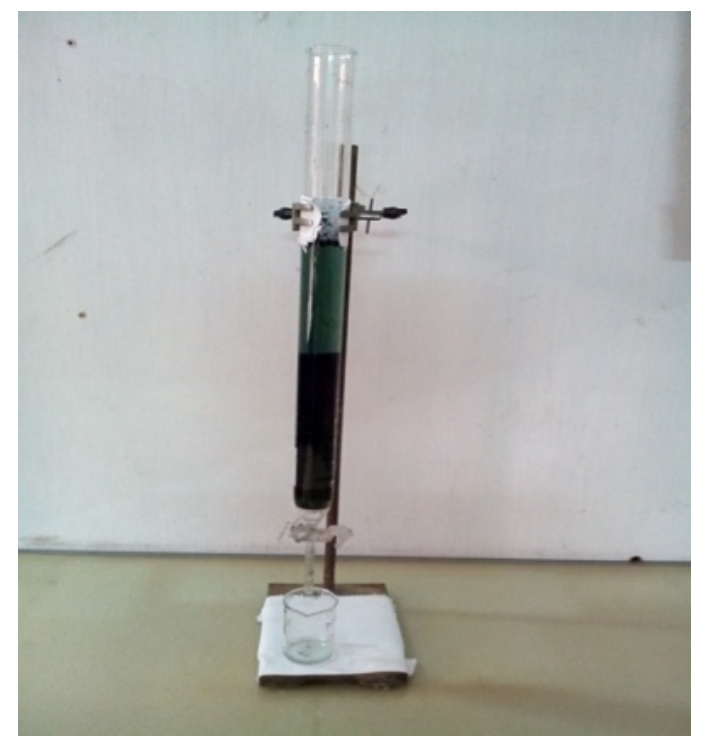

Fig. 2 Experimental column with passing sample solutions
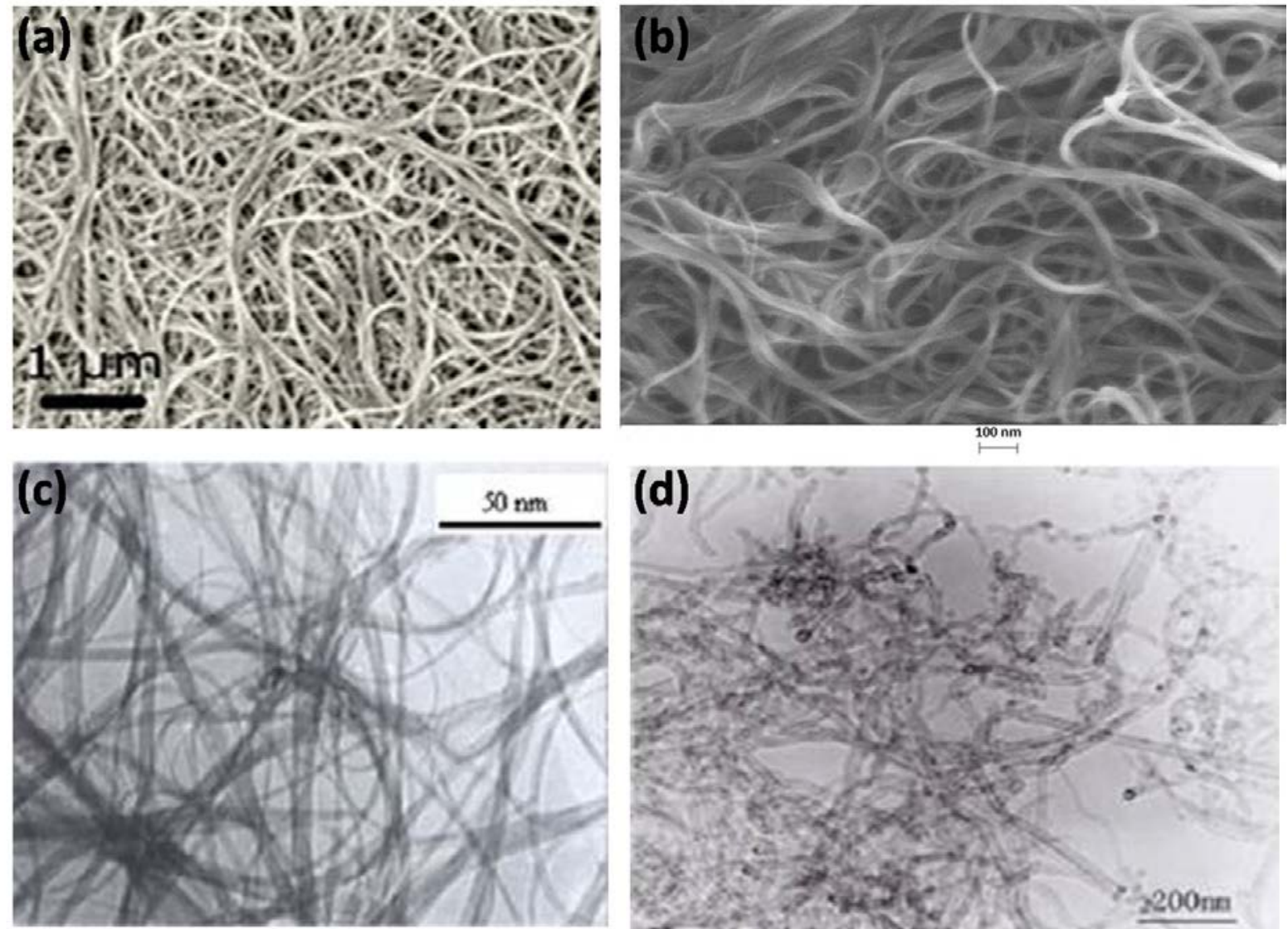
Fig. 3 (a) SEM images of carbon nanotubes bundles; (b) SEM micrograph of SWCNTs; (c) TEM images of SWCNTs and (d) TEM images of MWCNTs

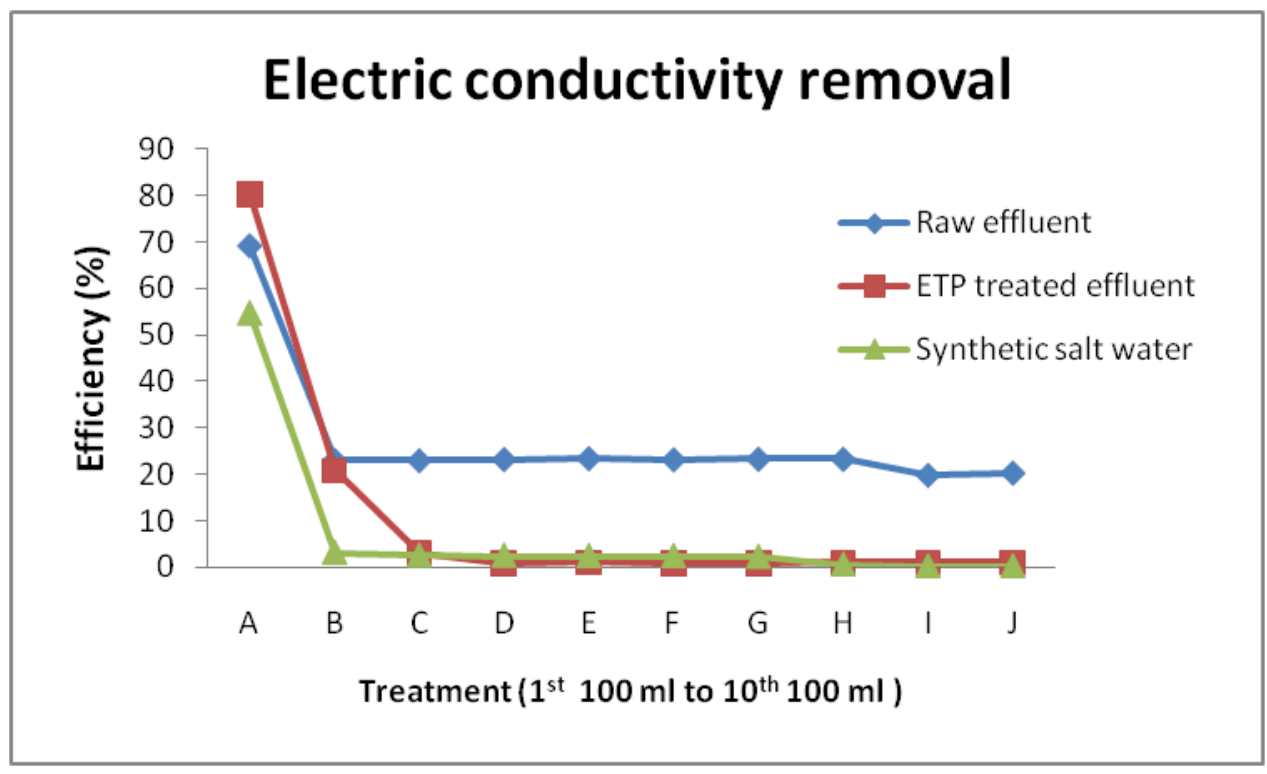

Fig. 4 Efficiency of CNTs for Electric conductivity removal of raw industrial effluent, ETP treated industrial effluent and synthetic salt water

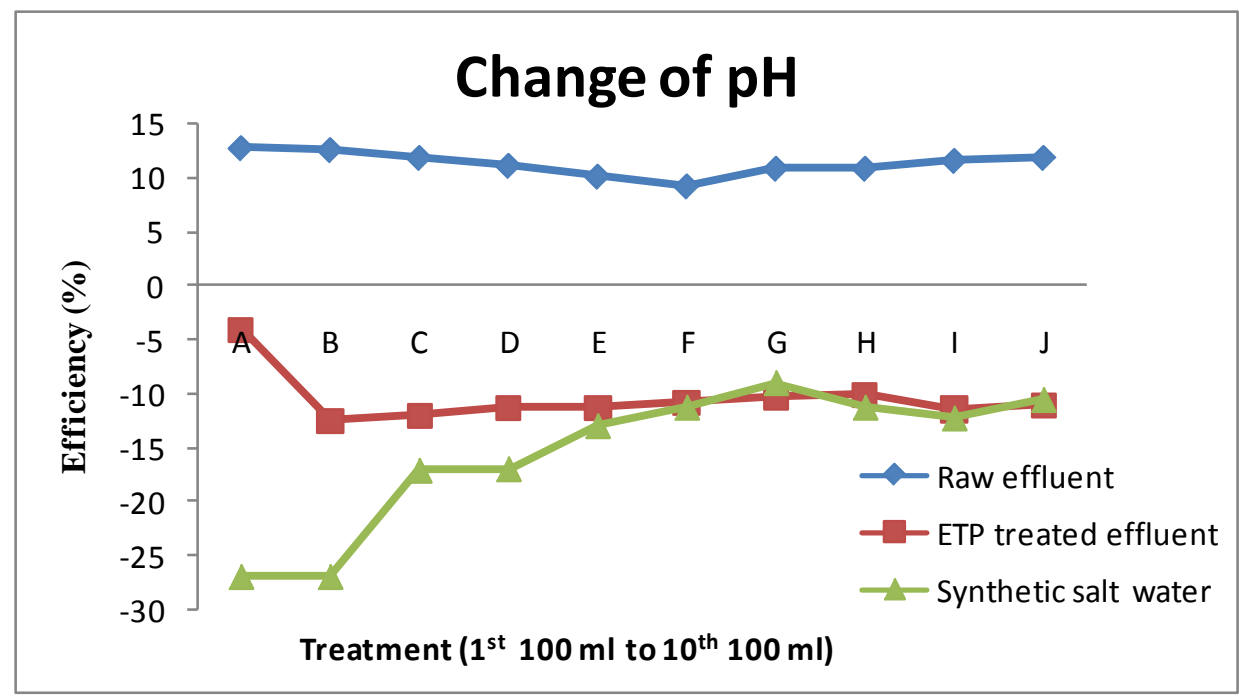

Fig. 5 Efficiency of CNTs in pH variation of raw industrial effluent, ETP treated industrial effluent and synthetic salt water 


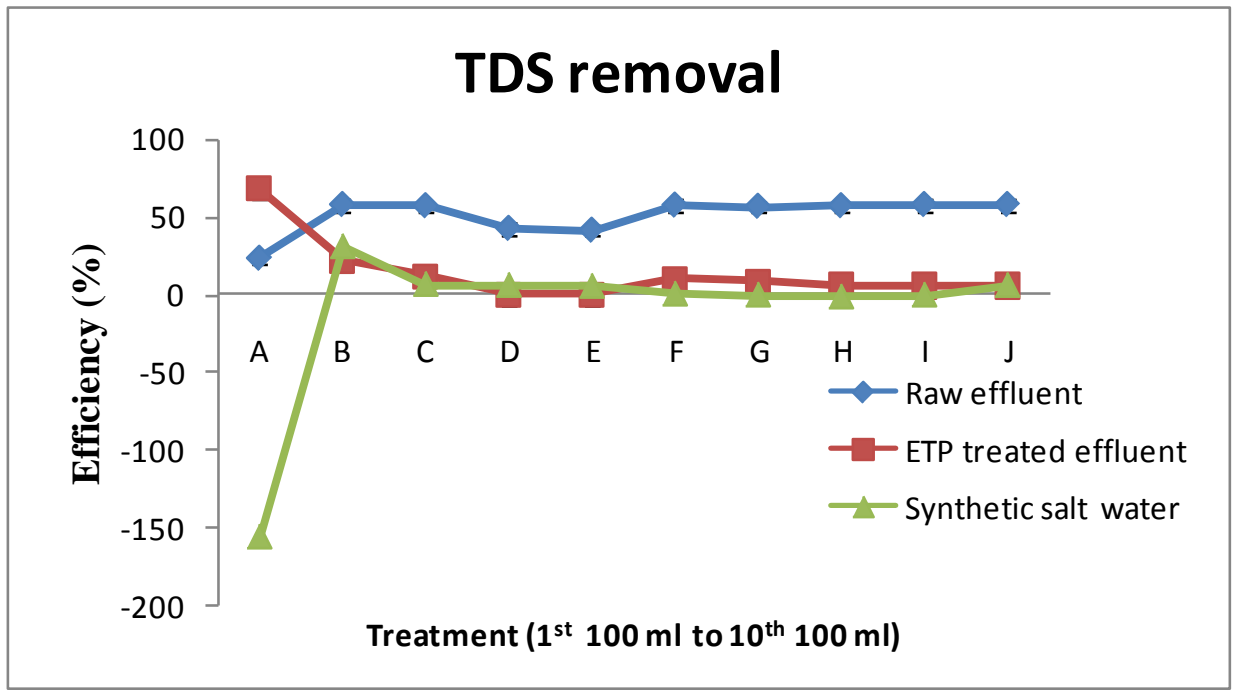

Fig. 6 Efficiency of CNTs for TDS removal of raw industrial effluent, ETP treated industrial effluent and synthetic salt water

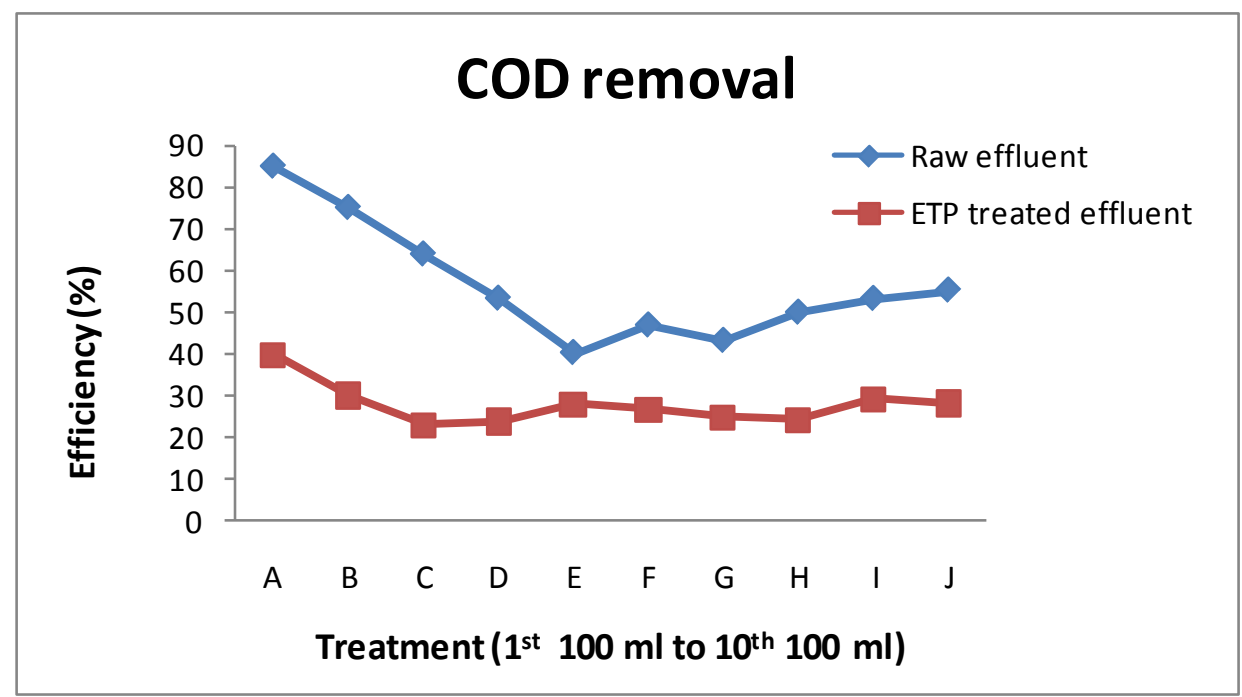

Fig. 7 Efficiency of CNTs for COD removal of raw industrial effluent and ETP treated effluent 


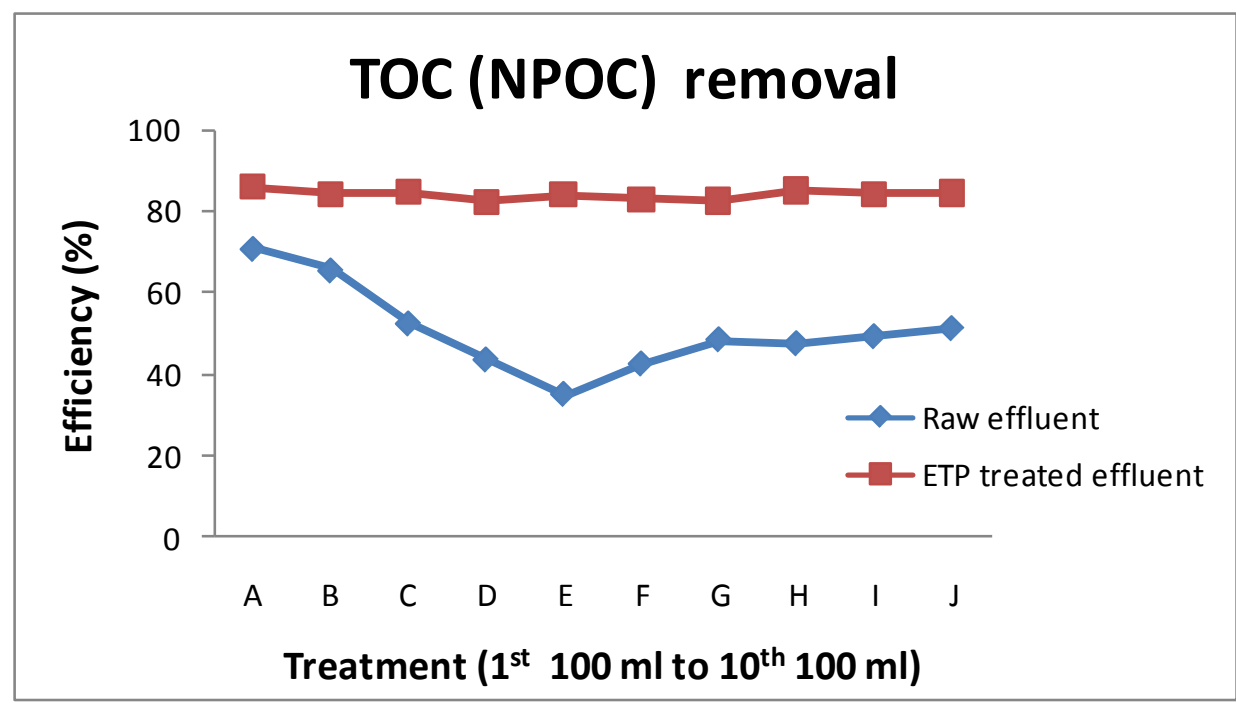

Fig. 8 Efficiency of CNTs for TOC (NPOC) removal of raw effluent and ETP treated effluent

Table 1 The physicochemical parameters wastewater before treatment

\begin{tabular}{llllll}
\hline Sample Water & $\begin{array}{l}\text { EC } \\
(\boldsymbol{\mu S} / \mathbf{c m})\end{array}$ & $\begin{array}{l}\text { TDS } \\
(\mathbf{m g} / \mathbf{l})\end{array}$ & $\mathbf{p H}$ & $\begin{array}{l}\text { COD } \\
(\mathbf{m g} / \mathbf{l})\end{array}$ & $\begin{array}{l}\text { TOC } \\
(\mathbf{N P O C}) \\
(\mathbf{m g} / \mathbf{l})\end{array}$ \\
\hline Raw effluent (I) & 3900 & 2620 & 10.9 & 788.8 & 1010 \\
ETP treated effluent (O) & 500 & 528 & 6.7 & 132.4 & 45.81 \\
Synthetic salt water (S) & 3000 & 1606 & 7.1 & - & - \\
\hline
\end{tabular}

Table 2 Determination of changes in EC after treatment by CNTs

\begin{tabular}{lccc}
\hline Treatment & \multicolumn{3}{c}{ Electric conductivity $(\mu \mathrm{S} / \mathrm{cm})$} \\
\cline { 2 - 4 } & Raw effluent $(\mathrm{I})$ & ETP treated effluent $(\mathrm{O})$ & Synthetic salt water $(\mathrm{S})$ \\
\hline Control & 3900.00 & 500.00 & 3000.00 \\
A & 1201.00 & 100.00 & 1400.00 \\
B & 3003.00 & 400.00 & 2990.00 \\
C & 3007.00 & 492.00 & 3009.00 \\
D & 2997.00 & 500.00 & 3011.00 \\
E & 2989.00 & 500.00 & 3013.00 \\
F & 2999.00 & 502.00 & 3014.00 \\
\hline
\end{tabular}




\begin{tabular}{llll}
\hline $\mathrm{G}$ & 2995.00 & 507.00 & 3020.00 \\
$\mathrm{H}$ & 2996.00 & 501.00 & 3070.00 \\
$\mathrm{I}$ & 3130.00 & 500.00 & 3080.00 \\
$\mathrm{~J}$ & 3111.00 & 500.00 & 3081.00 \\
\hline
\end{tabular}

Table 3 Determination of changes in $\mathrm{pH}$ after treatment by CNTs

\begin{tabular}{lccc}
\hline Treatment & \multicolumn{3}{c}{$\mathrm{pH}$} \\
\cline { 2 - 4 } & Raw effluent (I) & ETP treated effluent (O) & Synthetic salt water (S) \\
\hline Control & 10.90 & 6.65 & 7.05 \\
A & 9.50 & 6.92 & 8.95 \\
B & 9.52 & 7.48 & 8.95 \\
C & 9.60 & 7.45 & 8.26 \\
D & 9.68 & 7.40 & 8.25 \\
E & 9.79 & 7.40 & 7.97 \\
F & 9.89 & 7.37 & 7.85 \\
G & 9.71 & 7.34 & 7.69 \\
H & 9.71 & 7.32 & 7.85 \\
I & 9.63 & 7.41 & 7.92 \\
J & 9.60 & 7.39 & 7.80 \\
\hline
\end{tabular}

(A, B, C to J define $1^{\text {st }} 100 \mathrm{ml}, 2^{\text {nd }} 100 \mathrm{ml}, 3^{\text {rd }} 100 \mathrm{ml}$ to $10^{\text {th }} 100 \mathrm{ml}$ treated water, respectively )

Table 4 Determination of changes in TDS after treatment by CNTs

\begin{tabular}{lccc}
\hline \multirow{2}{*}{ Treatment } & \multicolumn{3}{c}{ Total Dissolved Solid (mg/L) } \\
\cline { 2 - 4 } & Raw effluent (I) & ETP treated effluent (O) & Synthetic salt water (S) \\
\hline Control & 26.00 & 52.00 & 16.00 \\
A & 55.00 & 17.00 & 61.00 \\
B & 11.00 & 41.00 & 11.00 \\
C & 11.20 & 46.00 & 14.90 \\
D & 15.00 & 52.00 & 15.00 \\
E & 15.30 & 52.00 & 15.10 \\
F & 11.10 & 47.00 & 15.90 \\
G & 11.30 & 48.00 & 16.00 \\
H & 11.20 & 49.00 & 16.20 \\
I & 11.00 & 49.20 & 16.00 \\
J & 11.00 & 49.00 & 15.00 \\
\hline
\end{tabular}

(A, B, C to J define $1^{\text {st }} 100 \mathrm{ml}, 2^{\text {nd }} 100 \mathrm{ml}, 3^{\text {rd }} 100 \mathrm{ml}$ to $10^{\text {th }} 100 \mathrm{ml}$ treated water, respectively )

Table 5 Determination of changes in COD after treatment by CNTs 


\begin{tabular}{lcc}
\hline Treatment & \multicolumn{2}{c}{ COD $(\mathrm{mg} / \mathrm{L})$} \\
\cline { 2 - 3 } & Raw effluent $(\mathrm{I})$ & ETP treated effluent $(\mathrm{O})$ \\
\hline Control & 788.80 & 132.40 \\
A & 120.30 & 80.00 \\
B & 198.50 & 92.70 \\
C & 286.60 & 102.00 \\
D & 370.30 & 100.90 \\
E & 473.10 & 95.80 \\
F & 421.00 & 97.00 \\
G & 450.20 & 99.40 \\
H & 396.80 & 100.60 \\
I & 370.70 & 93.80 \\
J & 354.90 & 95.20 \\
\hline
\end{tabular}

(A, B, C to J define $1^{\text {st }} 100 \mathrm{ml}, 2^{\text {nd }} 100 \mathrm{ml}, 3^{\text {rd }} 100 \mathrm{ml}$ to $10^{\text {th }} 100 \mathrm{ml}$ treated water, respectively )

Table 6 Determination of changes in TOC (NPOC) after treatment by CNTs

\begin{tabular}{lcc}
\hline Treatment & \multicolumn{2}{c}{ TOC(NPOC) $(\mathrm{mg} / \mathrm{L})$} \\
\cline { 2 - 3 } & Raw effluent $(\mathrm{I})$ & ETP treated effluent $(\mathrm{O})$ \\
\hline Control & 1010.00 & 45.81 \\
A & 295.00 & 6.47 \\
B & 348.80 & 7.20 \\
C & 480.90 & 7.01 \\
D & 570.60 & 8.14 \\
E & 656.50 & 7.40 \\
F & 580.80 & 7.92 \\
G & 520.40 & 8.01 \\
H & 530.10 & 6.90 \\
I & 512.70 & 7.26 \\
J & 492.58 & 7.12 \\
\hline
\end{tabular}

Table 7 Comparative analysis of removal efficiency of CNTs with some low-cost efficient adsorbent. 


\begin{tabular}{lllll}
\hline & $\begin{array}{l}\text { Activated } \\
\text { charcoal }\end{array}$ & Wood ash & Bagasse & CNTs \\
\hline pH & 6.6 & 5.9 & 6.1 & 6.65 \\
COD $\mathbf{~ m g} / \mathbf{L}$ & 968.4 & 941.34 & 739.65 & 80.00 \\
TDS $\mathbf{~ m g} / \mathbf{L}$ & 761.45 & 777.04 & 480.12 & 11.0 \\
$\mathbf{E C} \boldsymbol{\mu S} / \mathbf{c m}$ & $170 \mu \mathrm{S} / \mathrm{cm}$ & $210 \mu \mathrm{S} / \mathrm{cm}$ & $105 \mu \mathrm{S} / \mathrm{cm}$ & $100 \mu \mathrm{S} / \mathrm{cm}$ \\
TOC & 931.02 & 934.12 & 803.00 & 6.9 \\
\hline
\end{tabular}




\section{Reference}

1. Hossain, M.A.; Rahman, G.K.M.M.; Rahman, M.M.; Molla, A.H.; Rahman, M.M.; Uddin, M.K.: Impact of industrial effluents on growth and yield of rice (Oryza sativa L.) in silty clay loam soil. Journal of Environmental Sciences, 30, 231-240 (2015)

2. Shie, S.: Carbon Nanotube Usage for Desalination. COSMOS, Cluster 8 (2011)

3. Qu, X.; Alvarez, P.J.J.; Li, Q.: Applications of nanotechnology in water and wastewater treatment. Water Research, 47, 3931-3946 (2013)

4. Hossain, M.A.; Uddin, M.K.; Molla, A.H.; Afrad, M.S.I.; Rahman, M.M.; Rahman, G.K.M.M.: Impact of industrial effluents discharges on degradation of natural resources and threat to food security. The Agriculturists, 8 (2), 80-87 (2010)

5. Tinkle, A.S.: Nanotechnology: Collaborative opportunities for ecotoxicology and environmental health, Editorial. Environmental Toxicology and Chemistry. 27 (9), 1823-1824 (2008)

6. Alvarez, P.J.: Nanotechnology in the Environment-The Good, the Bad and the Ugly. Journal of Environmental Engineering. 132 (10), 1233 (2006)

7. Agboola, A.E.; Pike, R.W.; Hertwig, T.A.; Lou, H.H.: Conceptual design of carbon nanotube processes. Clean Technologies and Environmental Policy, 9 (4), 289 (2007)

8. Ong, Y.T.; Ahmad, A.L.; Zein, S.H.S.; Tan. S.H.: A review on carbon nanotubes in an environmental protection and green engineering perspective. Braz. J. Chem. Eng., vol.27 no.2 São Paulo Apr. ISSN 0104-6632 (2010)

9. Peng, X.; Li, Y.; Luan, Z.; Di, Z.; Wang, Hu.; Tian, B.; Jia, Z.: Adsorption of 1,2dichlorobenzene from water to carbonnanotubes. Chem. Phy. Lett., 376, 154. (2003)

10. Lu C.; Chung, Y.L.; Chang, K.F.: Adsorption of trihalomethanes from water with carbon nanotubes. Water Research 39, 1183-1189 (2005) 
11. Kondratyuk P.; Yates, J.T.: Jr, Desorption kinetic detection of different adsorption sites on opened carbon single walled nanotubes: the adsorption of n-nonane and CCl4 Chem. Phy. Lett. 410, 324-9 (2005)

12. Kun, Y.; Baoshan, X.: Adsorption of organic compounds by carbon nanomaterials in aqueous phase: polanyi theory and its application. Chemical reviews, 110, 5989-6008, (2010)

13. Xuemei, R.; Changlun, C.; Masaaki, N.; Xiangke, W.: Carbon nanotubes as adsorbents in environmental pollution management: A review. Chemical Engineering Journal, 170, 395-410, (2011)

14. Li, Y.H.; Ding, J.; Luan, Z.K.; Di, Z.C.; Zhu, Y.F.; Xu, C.L.; Wu, D.H.; Wei, B.Q.: Competitive adsorption of $\mathrm{Pb}^{2+}, \mathrm{Cu}^{2+}$ and $\mathrm{Cd}^{2+}$ ions from aqueous solutions by multiwalled carbon nanotubes. Carbon 41 (14), 2787e2792 (2003)

15. Lu, C.S.; Chiu, H.; Liu, C.T.: Removal of zinc(II) from aqueous solution by purified carbon nanotubes: kinetics and equilibrium studies. Industrial \& Engineering Chemistry Research 45 (8), 2850e2855 (2006)

16. Li Y.H.: Wang, S.; Cao, A.; Zhao, D.; Zhang, X.; Xu, C.; Luan, Z.; Ruan, D.; Liang, J.; Wu, D.; Wei, B.: Chem. Phy. Lett. 350, 412. (2001)

17. Sikder, M.T.; Yoshihiro, M.; Islam, M.S.; Saito, T, Tanaka, S.; Kurasaki, M.: Preparation and characterization of chitosan-caboxymethyl- $\beta$-cyclodextrin entrapped nanozero-valent iron composite for $\mathrm{Cu}$ (II) and Cr (IV) removal from wastewater. Chemical Engineering Journal, 236, 378-387, (2014)

18. Yang, R.T.: Adsorbents: Fundamentals and applications. John Wiley \& Sons, Inc. (2003) 
19. Mansoori, G.A.; Rohani.Bastami, T.; Ahmadpour, A.; Eshaghi Z.: Environmental application of nanotechnology. Annual Review of Nano Research, Vol. 2, Chap.2, 2008 (2008)

20. Corry, B.: Designing carbon nanotube membranes for efficient water desalination. The Journal of Physical Chemistry B. (2007).

21. World Health Organization: $\mathrm{pH}$ in Drinking-water; Background document for development of WHO Guidelines for Drinking-water Quality. Guidelines for drinking-water quality, 2nd ed. Vol. 2. Health criteria and other supporting information (1996)

22. Srivastava, A.; Srivastava, O.N.; Talapatra, S.; Vajtai, R.; Ajayan, P.M.: Carbon nanotube filters. Nature Materials, 3, 610-614 (2004)

23. Liu, X.; Zhang, S.; Pan, B.: Potential of Carbon Nanotubes in Water Treatment. http://dx.doi.org/10.5772/51332 (2012)

24. Pan, B.; Xing, B.S.: Adsorption mechanisms of organic chemicals on carbon nanotubes. Environmental Science and Technology 42, 9005-9013 (2008)

25. Colomer, J.F.; Stephan, C.; Lefrant, S.; Van Tendeloo, G.; Willems, I.; Kónya, Z.; Fonseca, A.; Laurent, C.; Nagy, J.B.: Large-scale synthesis of single-wall carbon nanotubes by catalytic chemical vapor deposition (CCVD) method. Chemical Physics Letters, 317 (1-2), 83 (2000)

26. Dalton, A.B.; Collins, S.; Razal, J.; Munoz, E.; Ebron, V.H.; Kim, B.G.; Coleman, J.N.; Ferraris, J.P.; Baughman, R.H.: Continuous carbon nanotube composite fibers: properties, potential applications, and problems, Journal of Materials Chemistry, 14, $1-3,(2004)$ 
27. Charu, S.; Sangeeta, M.: Evaluation of adsorbents efficacy for the removal of pollutants from sugar mill effluent. Journal of Agricultural and Biological Science, 7, 325-329.

28. Deepa, D.; Nehrukumar, V.; Chidambaranathan, V.: Synthesis and evaluation of functionalized carbon nanotubes (CNTs) based polymer composite nanofiltration membranes for desalination. International Journal of Advanced Technology in Engineering and Science, 3, 183-187, (2015).

29. Wang, H.; Wang, H. L.; Jiang, W. F.; Li, Z. Q.: Photocatalytic degradation of 2,4dinitrophenol (DNP) by multi-walled carbon nanotubes (MWCNTs)/TiO2 composite in aqueous solution under solar irradiation. Water Research, 43, 204-210, (2009) 